\title{
Surveillance of Individuals with a Family History of Pancreatic Cancer and Inherited Cancer Syndromes: A Strategy for Detecting Early Pancreatic Cancers
}

\author{
Hiroyuki Matsubayashi ${ }^{1,2, *\left(\mathbb{D}, \text { Yoshimi Kiyozumi }^{2}, \text { Hirotoshi Ishiwatari }^{1} \text {, Katsuhiko Uesaka }\right.}{ }^{3}$, \\ Masataka Kikuyama ${ }^{4}$ and Hiroyuki Ono ${ }^{1}$ \\ 1 Division of Endoscopy, Shizuoka Cancer Center, Shizuoka 411-8777, Japan; h.ishiwatari@scchr.jp (H.I.); \\ h.ono@scchr.jp (H.O.) \\ 2 Division of Genetic Medicine Promotion, Shizuoka Cancer Center, Shizuoka 411-8777, Japan; \\ y.kiyozumi@scchr.jp \\ 3 Division of Hepato-Biliary-Pancreatic Surgery, Shizuoka Cancer Center, Shizuoka 411-8777, Japan; \\ k.uesaka@scchr.jp \\ 4 Department of Gastroenterology, Tokyo Metropolitan Cancer and Infectious Diseases Center Komagome \\ Hospital, Tokyo 113-0021, Japan; kikuyama110@yahoo.ne.jp \\ * Correspondence: h.matsubayashi@scchr.jp; Tel.: +81-55-989-5222; Fax: +81-55-989-5692
}

Received: 13 October 2019; Accepted: 30 October 2019; Published: 31 October 2019

\begin{abstract}
A family history of pancreatic cancer (PC) is a risk factor of PC, and risk levels increase as affected families grow in number and/or develop PC at younger ages. Familial pancreatic cancer (FPC) is defined as a client having at least two PC cases in a first degree relatives. In the narrow sense, FPC does not include some inherited cancer syndromes that are known to increase the risks of PC, such as Peutz-Jeghers syndrome (PJS), hereditary pancreatitis (HP), hereditary breast ovarian cancer syndrome (HBOC), and so on. FPC accounts for $5 \%-10 \%$ of total PC diagnoses and is marked by several features in genetic, epidemiological, and clinicopathological findings that are similar to or distinct from conventional PC. Recent advances in genetic medicine have led to an increased ability to identify germline variants of cancer-associated genes. To date, high-risk individuals (HRIs) in many developed countries, including FPC kindreds and inherited cancer syndromes, are screened clinically to detect and treat early-stage PC. This article highlights the concept of FPC and the most recent data on its detection.
\end{abstract}

Keywords: familial pancreatic cancer; genetic; high risk; surveillance; treatment

\section{Introduction}

Pancreatic cancer (PC) is one of the most aggressive forms of cancer in humans. The overall prognosis is quite poor, and the five-year survival rate for cases of PC is $13 \%$. However, resection while the carcinoma is still limited to a minimal invasion ( $\leq 10 \mathrm{~mm}$ of tumor size) improves the five-year survival to $80 \%$ [1]. Hence, early detection and suitably timed resection are the ideal strategy to tackling PC. Recently, the possibility of detecting early PC has increased, following incidental findings uncovered during the clinical management of other diseases [2]. Early PC detection has also been achieved through screenings of high-risk individuals (HRIs), such as family members of PC patients and those with inherited cancer syndromes [3].

According to some previous case-controlled and cohort studies, it is clear that first degree relatives (FDRs) of PC patients face an increased risk of developing PC themselves (2.1 [4] -5.3 [5] odds ratio (OR) and 1.5 [6] -1.7 [7] relative risk (RR)) [8]. The incidence of PC rises with the number of family members with PC (standardized incidence ratio (SIR): 4.5 in families with one FDR of PC, 6.4 in two 
FDRs, and 32 in $\geq 3$ FDRs) [9]. In a general sense, having two or more PC patients as FDRs is a state defined as familial pancreatic cancer (FPC) [10], which accounts for $5-10 \%$ of all PC cases. In a more narrow sense, known genetic syndromes are excluded from this condition [9] (see Supplementary Table S1), these include Peutz-Jeghers syndrome (PJS) [11], hereditary pancreatitis (HP) [12], familial atypical multiple mole melanoma (FAMMM) [13,14], hereditary breast-ovarian cancer (HBOC) $[15,16]$, Lynch syndrome (LS) [17,18], and familial adenomatous polyposis (FAP) [19].

Since the 1990s, many countries and institutions have established FPC registries, and clinical observational studies have been concluded on the early detection and cure of PCs that develop among HRIs.

\section{Characteristics of FPC}

\subsection{Epidemiology}

FPC is remarkable for epidemiological characteristics relative to ordinary PC. As similar to sporadic PC (SPC) cases, smoking [8,20] and diabetes [8] are both risk factors for FPC, and an earlier onset of the disease is common among smokers in FPC (the typical onset for smokers is 63.7 years, while it is 66.6 years for non-smokers, $p=0.05$ ) [20]. Ethnic deviations have been a concern for Ashkenazi Jews, as they represent a genetically distinct population [21] characterized by a higher than average prevalence of germline variants in BRCA1, BRCA2, MSH2, and MSH6 [22,23]. Upon closer review of New York City death certificates, it becomes clear that there is a higher mortality rate due to PC among Jewish groups than non-Jews (RR: 1.43, to compared with non-Jewish patients). Despite the above, a recent study from Harvard University has identified Ashkenazi Jews' hazard ratio (HR) by family history of PC as 2.79 [24], which is not remarkable when compared with worldwide data [25]. Another recent study that analyzed the Utah Population Database found 4095 cases of PC and 40,933 controls. The database revealed a higher risk of PC among the FDRs of female PC patients (RR: 1.96) and in the FDRs of younger PC patients ( $<65$ years, RR: 2.12) [26]. The lifetime risk of PC increases with the decreasing age of PC onset in family members [27,28], while the SIR (9.31) in members of FPC kindreds with young onset $(<50$ years) PC is higher than those without (SIR: 6.34) $(p<0.001)$. Two European FPC registries [29-31], the European Registry of Hereditary Pancreatitis and Familial Pancreas Cancer (EUROPAC) and the German National Case Collection for Familial Pancreatic Carcinoma (FaPaCa), analyzed 106 FPCs over three generations and observed a trend of younger onset and worse prognoses among the youngest generation [32].

\subsection{Pathology}

The histology of the pancreas in FPC kindreds often demonstrates multiple precancerous lesions [33], including pancreatic intraepithelial neoplasm (PanIN) and intraductal papillary mucinous neoplasm (IPMN) [34,35]. These precancerous lesions were more often recognized in PFCs' pancreases than in SPC patients (2.8-fold, $p<0.05$ ); this is a remarkable trend for incipient IPMNs (11.8-fold) [36]. The pancreases of FPC kindred are sometimes associated with parenchymal atrophy and early chronic pancreatitis changes, which can be observed via endoscopic ultrasonography (EUS) [35].

Despite the differences in these precursor lesions [33,35], a blind analysis of histological observations by expert pathologists found no significant differences between the cancerous tissues of 519 FPCs and 561 SPCs in terms of their location, lymph node metastasis, neural invasion, pathological stage, tumor size, or vessel permeation [37].

\subsection{Molecular Biology}

The genome-wide allelic status [38,39], genetic (somatic mutation of K-ras, TP53, and DPC4), and epigenetic (promoter methylation of SPARC, NPTX2, CDKN2A, etc.) alterations frequently observed in PC [40] have been compared between SPCs and FPCs, but no obvious difference has yet been recognized. 


\subsection{Germline Variants}

Unlike other familial tumors, germline pathogenic variants have been proven in fewer than $20 \%$ of FPC cases [3]. Recently, variants of genes functioning in the homologous recombination (HR) pathway have been considered not only in terms of surveillance, but also as they relate to treatments [41]: ATM (variant rate: 2-4\%) [42,43], BRCA1 (0-7\%) [44,45], BRCA2 (4-17\%) [15,43,46], CHEK2 (1-6\%) [47], PALB2 (1-4\%) [43,48,49], and RAD51 (4\%).

Carriers of $B R C A 1 / 2$ variants have a modest risk for PC (relative risks: $2-8 \%$; lifetime risks: $2-17 \%$ ), but other specific variants have greater increased risks. For instance, BRCA2 6174delT, a Jewish founder variant, was detected in $13 \%$ of Jewish PC cases (OR: 12.8 [50]). The BRCA2 K3326X variant was detected in $5.6 \%$ of 144 American FPC cases, a significantly more common rate than among SPCs [51]. A murine experimental model demonstrated that a germline $B R C A 2$ variant [52] promoted carcinogenesis via the K-ras mutation [53], which confirms the function of the $B R C A 2$ mutation in FPC. Apart from these genes associated with the HR pathway, variants of those genes responsible for several inherited cancer syndromes (see Supplementary Table S1) are also causative for FPCs, in a general sense.

Recently, precision medicine, a new cancer treatment strategy, has been applied to the treatment of advanced cancers. One result has been that unexpected variants of cancer-associated genes are now detected as increasing rates [54]. Commercially available tests also include a panel of genes known to be causative for FPCs. Above all, variants of HR-associated genes $[42-48,55]$ and mismatch repair genes [56] are often recognized and related to the drug choice (poly ADP-ribose polymerase (PARP) inhibitor [41] and immune checkpoint inhibitor [57], respectively).

\section{Clinical Managements for the Individuals with Inherited Risk of PC}

\subsection{FPC Registries}

The notion of a FPC registry emerged with the establishment of the National Familial Pancreas Tumor Registry (NFPTR) at Johns Hopkins University (Baltimore, UUS), in 1994 [58]. This was soon followed by the EUROPAC, in 1997 [29], at Liverpool University, in the UK, and the FaPaCa [30] at Phillips University, in Marburg, Germany, in National FPC registries have also been established in Italy (2007) [59], Spain (2009) [60], Australia (2011), and Japan (Japanese Familial Pancreatic Cancer Registry, JFPCR) (2014) [61].

At present, the JFPCR is planning a prospective cohort study of FPCs and their relatives; its primary goal will be to investigate the etiology of FPC and to clarify the basic and clinical issues Japanese FPCs face. Japanese experts, such as researchers, clinicians, genetic counselors, and statisticians from 21 hospitals nationwide have discussed and proposed a FPC management system. As of January 2019, 98 families and 678 HRIs had been registered with the JFPCR. JFPCR has established the expert consensus for managing the HRIs of PC (2019) and HRIs are recommended to be screened for the pancreas by the combination of image modality and blood test every six months.

\subsection{Targeted Lesions}

Worldwide experts in PC gathered at the International Symposium on Inherited Diseases of the Pancreas [62] and International Cancer of the Pancreas Screening Consortium (CAPS) (2011) [63] to discuss PC screening targets and concluded that prior screening programs for HRIs have aim to detect and treat high-grade precursors (high-grade PanIN [34] and IPMN [64]) or UICC-stage IA PC (T1N0M0) [63]. The five-year survival rate of UICC stage IA cancer is $68.7 \%$. Thus, the ideal targeted lesion is thought to be a high-grade precursor or UICC-stage 0 PC (five-year survival: 85.8\%) [1].

\subsection{High-Risk Individuals (HRIs)}

Several consortiums have recommended that those with a 5- [63,65] to 10-fold [62] risk undergo PC screening. Candidates' risk profiles are determined based on their numbers of affected family 
members and hereditary syndromes (germline mutated genes) (see Supplementary Table S1). The CAPS consortium proposed nine conditions for screening candidates (see Supplementary Table S2). The risk factors that have been associated with lifestyle and pancreatic diseases should also be taken into consideration as a part of the screening process, such as smoking $[8,66]$, obesity $[67,68]$, physical inactivity [68], diabetes [8,62,69], chronic pancreatitis [62,70,71], IPMN [64], pancreatic cysts [72], pancreatic duct ectasia [72], and so on. For instance, a patient who smokes and has diabetes mellitus with one FDR with PC has a 10-fold risk odd for developing PC, compared to negative controls [8]. Therefore, any counseling provided to HRIs should include information concerning modifiable lifestyle risks, and their improvement should be recommended (i.e., smoking cessation, a healthy diet high in fruits and vegetables, and regular exercise to control weight (body mass index: $<25 \mathrm{~kg} / \mathrm{m}^{2}$ ) [62].

\subsection{Timing of Screening Initiation and Intervals}

In many institutions, PC screens begin at age 40 [73,74], or 10 years younger than the age of the youngest relative with PC [30,75]. Given that PC develops in cases of PJS at a young age (average onset: 40.8 years) [11], their screenings typically start at 30 [73]. When we consider screenings' effectiveness, we know that the detection of pancreatic lesions increases after the ages of 50-60 [76], so more than half $(51 \%)$ of the experts in the CAPS consortium have voted for initial screenings for standard FPC kindreds to begin at age 50 [63].

In addition to the above, many institutions recommend yearly screenings, so long as a patient's latest pancreas image is normal [63]. However, once an abnormal finding is observed, subsequent screenings are conducted every 3-6 months $[31,73,77]$ or every 3-12 months [63]. Other endorsed screening intervals are: 6-12 months for a non-suspicious cyst; 3 months for a newly detected solid lesion, if surgery is not imminent; and 3 months for an indeterminate main pancreatic duct stricture. FPCs' natural histories and progressions still require study before judging the appropriate screening intervals based on risk level.

\subsection{Screening Modalities}

Although no full consensus was reached in the CAPS meeting [63], EUS is regarded as the most suitable PC screening modality, based on its ability to detect small pancreatic lesions $(<1 \mathrm{~cm})[73,78]$. EUS is also superior at detecting risk findings frequently seen among HRIs, such as duct ectasia, parenchymal findings of the pancreas [35], and cysts [72]. Drawbacks associated with EUS include the need for a relatively long fasting period and conscious sedation; operator-dependent visualization and interpretation [79]; and a limited observation area, in cases where a patient has a reconstructed upper gastrointestinal tract. In this sense, abdominal ultrasonography is a handy tool that may be substituted for EUS, if the pancreas is well visualized without any blind spots [72]. MRI and magnetic resonance cholangiopancreatography (MRCP) are also useful for visualizing the pancreatic ductal systems. Dilation of the pancreatic duct and cyst formation are risk factors for PC [72] and are frequently recognized among HRIs (cysts in 38.9\% and duct ectasia in 2.3\%) [76]. EUS and MRI are considered the most accurate imaging tools with high agreement among the consortium experts (agreement, EUS: 83.7\% and MRI/MRCP: 73.5\%) [63]. In addition to image analyses, serum tumor markers, including carcinoembryonic antigen and cancer antigen 19-9, should be checked at every screening [63,75].

\subsection{Image findings Among HRIs}

When investigating individuals with inherited PC, clinical images of their pancreases show a variety of characteristic findings. On the EUS, HRIs demonstrate several findings often seen in early chronic pancreatitis: cysts, high echoic foci, lobularity, strandings, and a high-echoic margin of the main pancreatic duct (MPD) [80]. However, these EUS findings are not truly specific to FPC kindreds, so any interobserver agreement for these findings is limited to the fair level, even among expert endosonographers $(\kappa<0.4)[81]$. 
Pancreatic investigations using computed tomography (CT), MRI, and EUS conducted in five US academic medical centers demonstrated pancreatic findings in $42 \%$ of 216 asymptomatic HRIs; these included cysts (39\%, mean: $0.55 \mathrm{~cm}$ in size), pancreatic duct dilation $(2.3 \%)$ and solid mass $(1.4 \%)$, and an increasing trend by age ( $14 \%$ among those $<50$ years, $34 \%$ in patients $50-59$ years, and $53 \%$ in $60-69$ years; $p<0.0001)$ [76]. A recent study by the EUROPAC also detected $41(13 \%)$ cystic lesions in 321 FPC kindred individuals [82].

A collaborative study by the Leiden FPC Group and FaPaCa demonstrated that pancreatic cystic lesions, or IPMNs, were frequently recognized in FPC kindreds (some of this group carried BRCA2 and PALB2 variants) than in CDKN2A/p16 (p16-Leiden) variant carriers (42\% vs. $16 \%$ ). Cystic lesions were mostly stable in the FPC cohorts, while the malignant transformation of the cyst was more common $(0.8 \%$ in the FPC cohort vs. $7 \%$ in the $p 16$-Leiden cohort) [83]. A similar outcome was observed in a Dutch cohort study (Dutch Research Group on Pancreatic Cancer Surveillance in High-risk Individuals) [84]. They reported that pancreatic cystic lesions ( $10 \mathrm{~mm}$ or greater in size) were more likely to be seen in 88 FPC kindreds without germline variants than in 98 variant carriers $(16 \%$ vs. $5 \%, p=0.045)$. However, pancreatic cysts were significantly more likely to progress in the variant carriers than in the non-carrier group ( $16 \%$ vs. $2 \%, p=0.05)$ [84].

IPMNs were sometimes recognized in cases with PJS (STK11/LKB1 variant) [85] and FAP (APC variant) [86]. Variants of cystic fibrosis transmembrane conductance regulator (CFTR) [87], serine protease inhibitor Kazal type 1 (SPINK1), and cationic trypsinogen (PRSS1) [88] develop PC during long-standing chronic pancreatitis, so that PC can be accompanied by severe pancreatic atrophy, pancreatic stones, and duct ectasia. PC with microsatellite instability is reported to be concordant with the medullary growth histology and negative for somatic K-ras mutation [89]. Our previous study showed a unique histology, that of a dendritic structure, of PC in a case with a germline PTEN variant [90]. Further data accumulation is needed for solid evidence; however, the image findings among HRIs may vary depending on the associated genetic changes.

\subsection{Pathological Sampling for the Detection of Early Pancreatic Cancer (Proposal)}

EUS-guided fine needle aspiration (EUS-FNA) and endoscopic retrograde cholangiopancreatography (ERCP) are useful in obtaining pathological evidence when abnormal findings are observed in surveillance images [73-75]. Hence, clinicians must be cautious about suspicious pancreatic findings, such as pancreatic masses, enhanced nodules, pancreatic duct stenosis/narrowing, and focal pancreatic atrophy [2].

Our diagnostic strategy is summarized in Figure 1 In cases with a visible pancreatic mass of uncertain malignancy, EUS-FNA is performed even for masses sized $\leq 1 \mathrm{~cm}$ [91-93]. In cases of ductal lesions, either stenotic or ectatic, with or without (localized) pancreatic atrophy, the preferred strategy is pancreatic juice extraction for cytology using endoscopic naso-pancreatic ductal drainage (ENPD) [94,95], as small PCs tended to extend intraductally, compared with the larger ones [96]. An ENPD test should be avoided in cases with a high risk of post-ERCP pancreatitis, such as those with rich pancreatic parenchyma, a normal MPD width, pancreatic divisum, the secretion of highly viscous mucus that may stick inside an ENPD, etc. Pre-surgical EUS-FNA from the image-typical cancer lesions at the pancreas' body and tail are controversial, because of the possibility of cancer seeding [97]. Indications for these examinations should be discussed among experts at each institution prior to their use. 


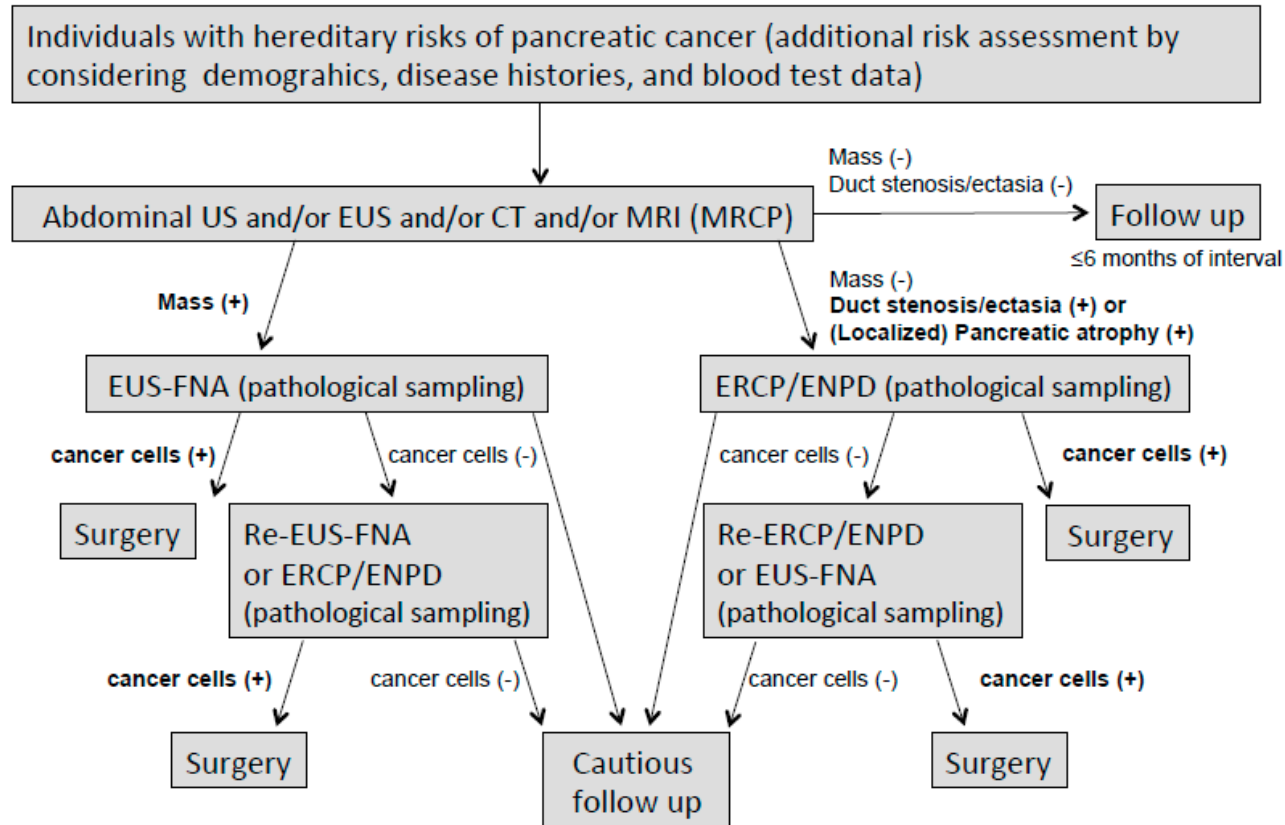

Figure 1. Proposal of surveillance and investigation of individuals with inherited risks of pancreatic cancer.

\subsection{Surgical Indications and Procedures}

The extent of cancer-related resections is controversial, depending on the therapeutic concept. In this context, the choices are the removal of all precancerous lesions [75] or the resection of only a targeted area that includes nodular or cystic lesions [73]. In cases of HBOC with the BRCA mutation, risk-reducing salpingo-oophorectomy is not only affordable, it also has an acceptable level of complications [98]. However, for the pancreas, prophylactic total pancreatectomy has severe complications, including a considerable level of postsurgical in-hospital mortality (5-23\% in Germany) [99,100] and subsequent serious glycemic control failure (mortality: 4-8\% per year) [101]. A secondary pancreatectomy for the remnant pancreas can be conducted without increasing morbidity and mortality [102], so resection of the target area, rather than a total pancreatectomy, has been preferable to date. Despite the above, a total pancreatectomy combined with islet autotransplantation has been applied to cases of HP with long-standing pain that has been untreatable by medicine. Even more recently, due to the improvements in post-surgical quality of life, this operation is now indicated for FPC kindred with premalignant lesions [101,103]. Further improvements are expected in the future.

\subsection{Present Outcomes of Surveillance}

Several surveillance results have been reported by Western FPC registries (see Supplementary Table S3) $[3,31,73,77,80,104-110]$. Roughly $2-19 \%$ of the HRIs screened underwent surgery for suspected lesions. Among these, about one fifth were borderline precursors and carcinoma in situ, or definitive targets of the surveillance, while $30-40 \%$ of the resected cases were benign lesions. A small proportion of PC was resected at an early phase (T1NOM0), and some PC cases were detected at the unresectable stage. These outcomes are far from the goal of the surveillance. However, a recent study at Johns Hopkins demonstrated a three-year survival rate of ten PC cases diagnosed during surveillance was $85 \%$, significantly longer than those detected outside the surveillance study $(p=0.0009)$. In addition, all ten cases with high-grade PanIN (PanIN3) or high-grade IPMN were alive after surgery (4.1-14.7 years). These data suggest that recent surveillance systems are improving and prolonging the PC-associated survival rate among HRIs [77]. 


\title{
3.10. Application of Blood Circulating Biomarkers for Detecting Early Pancreatic Cancer
}

Blood circulating biomarkers for detecting early pancreatic cancers have been discovered including circulating tumor DNA [111,112], exome-derived DNA [113], MicroRNA [114] (miR-93, miR-16, miR-548d-3p, etc.), and proteins [115] (SYCN, REG1B, PRSS2, etc.). Liu et al. [112]. reported that 791 cancer-specific cell free DNA fragments with mutations were detected in plasma of $88 \%$ of total PC patients and K-ras hotspot mutation detected in $72 \%$ of stage I/II PC patients. Allenson et al. [113] reported exome-derived K-ras mutant DNA was detected in $44 \%$ of early-stage PC patients and $20 \%$ of healthy controls. These promising biomarkers can be applied to the screening of the asymptomatic HRIs of PC.

\section{Pharmacological Treatments for Familial Pancreatic Cancer}

Today, FOLFIRINOX (fluorouracil, folic acid, irinotecan, and oxaliplatin) and gemcitabine-based regimens are standard chemotherapy regimens for unresectable PCs [116]. In cases of advanced PCs with $B R C A$ variants, superior overall survival was recognized in the cases treated by platinum-based chemotherapies than those by non-platinum agents (22 months and 9 months, $p=0.04$ ) [117]. A similar trend was observed in the progression-free survival after the initiation of oxaliplatin-based chemotherapy in cases with PCs; between PCs with and without somatic mutations of homologous recombination-related genes (20.8 months in mutant group vs. 1.7 months in wild-type group, $p=0.049$ ) [118]. In a most recent study, a randomized, double-blind, phase 3 trial (Pancreas Cancer Olaparib Ongoing trial: POLO trial) for germline $B R C A$-variant cases with a metastatic PC, that had not progressed during first-line platinum-based chemotherapy, demonstrated a significantly longer progression-free survival in the oraparib (poly (adenosine diphosphate-ribose) polymerase inhibitor) group (7.4 months) than in the placebo group (3.8 months) (hazard ratio: $0.53, p=0.004$ ), although their overall survivals by an interim analysis were not different between the two groups (median: 18.9 months vs. 18.1 months; hazard ratio: $0.91, p=0.68$ ) [41].

\section{Conclusions}

FPCs have several characteristics that are similar to SPCs, and many others that differentiate them from the group. A family history of PC and certain genetic syndromes should be taken into consideration when screening candidates in hopes of detecting early PC. To date, scientific data regarding FPCs has been gathered via family registries. Genetic information about these HRIs can have an influence on their clinical management, and even on the treatment choice offered to them. The outcomes of HRIs' screenings have improved in recent decades, but remain unsatisfactory. Further innovation and long-term studies are expected to detect early phase PC, the king of human cancers.

Supplementary Materials: Supplementary materials can be found at http://www.mdpi.com/2075-4418/9/4/169/s1.

Author Contributions: H.M. drafted the manuscript; H.I., M.K., Y.K., and K.U. provided beneficial comments from the viewpoints of an endoscopist, a genetic counselor and a surgeon, and H.O. supervised the manuscript. All authors reviewed and approved the final version of the manuscript.

Funding: This research received no external funding.

Conflicts of Interest: The authors declare no conflicts of interest.

\author{
Abbreviations \\ CAPS International Cancer of the Pancreas Screening Consortium \\ EUROPAC European Registry of Hereditary Pancreatitis and Familial Pancreas Cancer \\ EUS endoscopic ultrasonography \\ EUS-FNA endoscopic ultrasonography-guided fine needle aspiration \\ FAMMM familial atypical multiple mole melanoma \\ FAP familial adenomatous polyposis \\ FaPaCa German National Case Collection for Familial Pancreatic Carcinoma \\ FDR first-degree relative
}




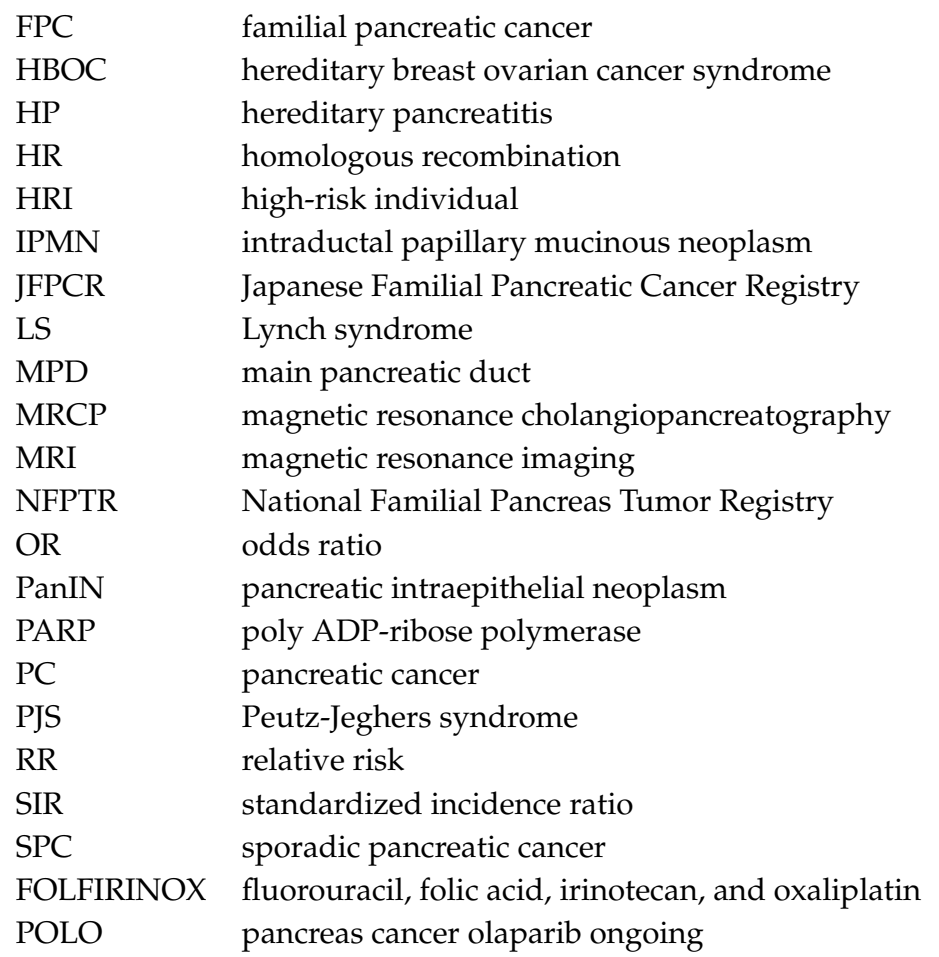

\section{References}

1. Egawa, S.; Toma, H.; Ohigashi, H.; Okusaka, T.; Nakao, A.; Hatori, T.; Maguchi, H.; Yanagisawa, A.; Tanaka, M. Japan Pancreatic Cancer Registry; 30th year anniversary: Japan Pancreas Society. Pancreas 2012, 41, 985-992. [CrossRef] [PubMed]

2. Kanno, A.; Masamune, A.; Hanada, K.; Maguchi, H.; Shimizu, Y.; Ueki, T.; Hasebe, O.; Ohtsuka, T.; Nakamura, M.; Takenaka, M.; et al. Multicenter study of early pancreatic cancer in Japan. Pancreatol. 2018, 18, 61-67. [CrossRef] [PubMed]

3. Matsubayashi, H.; Takaori, K.; Morizane, C.; Maguchi, H.; Mizuma, M.; Takahashi, H.; Wada, K.; Hosoi, H.; Yachida, S.; Suzuki, M.; et al. Familial pancreatic cancer: Concept, management and issues. World J. Gastroenterol. 2017, 23, 935-948. [CrossRef] [PubMed]

4. Inoue, M.; Tajima, K.; Takezaki, T.; Hamajima, N.; Hirose, K.; Ito, H.; Tominaga, S. Epidemiology of pancreatic cancer in Japan: a nested case-control study from the Hospital-based Epidemiologic Research Program at Aichi Cancer Center (HERPACC). Int. J. Epidemiol. 2003, 32, 257-262. [CrossRef]

5. Falk, R.T.; Pickle, L.W.; Fontham, E.T.; Correa, P.; Fraumeni, J.F. LIFE-STYLE RISK FACTORS FOR PANCREATIC CANCER IN LOUISIANA: A CASE-CONTROL STUDY. Am. J. Epidemiol. 1988, 128, 324-336. [CrossRef]

6. Coughlin, S.S.; Calle, E.E.; Patel, A.V.; Thun, M.J. Predictors of pancreatic cancer mortality among a large cohort of United States adults. Cancer Causes Control. 2000, 11, 915-923. [CrossRef]

7. Hemminki, K.; Li, X. Familial and second primary pancreatic cancers: a nationwide epidemiologic study from Sweden. Int. J. Cancer 2003, 103, 525-530. [CrossRef]

8. Matsubayashi, H.; Maeda, A.; Kanemoto, H.; Uesaka, K.; Yamazaki, K.; Hironaka, S.; Miyagi, Y.; Ikehara, H.; Ono, H.; Klein, A.; et al. Risk Factors of Familial Pancreatic Cancer in Japan: Current Smoking and Recent Onset of Diabetes. Pancreas 2011, 40, 974-978. [CrossRef]

9. Klein, A.P. Prospective Risk of Pancreatic Cancer in Familial Pancreatic Cancer Kindreds. Cancer Res. 2004, 64, 2634-2638. [CrossRef]

10. Petersen, G.M. Familial pancreatic cancer. Semin. Oncol. 2016, 43, 548-553. [CrossRef]

11. Giardiello, F.M.; Brensinger, J.D.; Tersmette, A.C.; Goodman, S.N.; Petersen, G.M.; Booker, S.V.; Cruz-Correa, M.; Offerhaus, J.A. Very high risk of cancer in familial Peutz-Jeghers syndrome. Gastroenterol. 2000, 119, 1447-1453. [CrossRef] [PubMed] 
12. Whitcomb, D.C.; Applebaum, S.; Martin, S.P. Hereditary pancreatitis and pancreatic carcinoma. Ann. New York Acad. Sci. 1999, 880, 201-209. [CrossRef] [PubMed]

13. Lynch, H.T.; Fusaro, R.M.; Lynch, J.F.; Brand, R. Pancreatic cancer and the FAMMM syndrome. Fam Cancer 2008, 7, 103-112. [CrossRef] [PubMed]

14. Vasen, H.; Gruis, N.; Frants, R.; Van Der Velden, P.; Hille, E.; Bergman, W.; Gruis, N. Risk of developing pancreatic cancer in families with familial atypical multiple mole melanoma associated with a specific 19 deletion of p16 (p16-Leiden). Int. J. Cancer 2000, 87, 809-811. [CrossRef]

15. Murphy, K.M.; Brune, K.A.; Griffin, C.; Sollenberger, J.E.; Petersen, G.M.; Bansal, R.; Hruban, R.H.; Kern, S.E. Evaluation of candidate genes MAP2K4, MADH4, ACVR1B, and BRCA2 in familial pancreatic cancer: deleterious BRCA2 mutations in 17\%. Cancer Res. 2002, 62, 3789-3793.

16. Breast Cancer Linkage, C. Cancer risks in BRCA2 mutation carriers. J. Natl. Cancer Inst. 1999, 91, 1310-1316. [CrossRef]

17. Kastrinos, F.; Mukherjee, B.; Tayob, N.; Wang, F.; Sparr, J.; Raymond, V.M.; Bandipalliam, P.; Stoffel, E.M.; Gruber, S.B.; Syngal, S. Risk of pancreatic cancer in families with Lynch syndrome. JAMA 2009, 302, 1790-1795. [CrossRef]

18. Aarnio, M.; Sankila, R.; Pukkala, E.; Salovaara, R.; Aaltonen, L.A.; De La Chapelle, A.; Peltomäki, P.; Mecklin, J.; Järvinen, H.J. Cancer risk in mutation carriers of DNA-mismatch-repair genes. Int. J. Cancer 1999, 81, 214-218. [CrossRef]

19. Giardiello, F.M.; Offerhaus, G.J.; Lee, D.H.; Krush, A.J.; Tersmette, A.C.; Booker, S.V.; Kelley, N.C.; Hamilton, S.R. Increased risk of thyroid and pancreatic carcinoma in familial adenomatous polyposis. Gut 1993, 34, 1394-1396. [CrossRef]

20. Yeo, T.P.; Hruban, R.H.; Brody, J.; Brune, K.; Fitzgerald, S.; Yeo, C.J. Assessment of “Gene-Environment” Interaction in Cases of Familial and Sporadic Pancreatic Cancer. J. Gastrointest. Surg. 2009, 13, 1487-1494. [CrossRef]

21. Behar, D.M.; Yunusbayev, B.; Metspalu, M.; Metspalu, E.; Rosset, S.; Parik, J.; Rootsi, S.; Chaubey, G.; Kutuev, I.; Yudkovsky, G.; et al. The genome-wide structure of the Jewish people. Nat. 2010, 466, 238-242. [CrossRef] [PubMed]

22. Stadler, Z.K.; Salo-Mullen, E.; Patil, S.M.; Pietanza, M.C.; Vijai, J.; Saloustros, E.; Hansen, N.A.; Kauff, N.D.; Kurtz, R.C.; Kelsen, D.P.; et al. Prevalence of BRCA1 and BRCA2 mutations in Ashkenazi Jewish families with breast and pancreatic cancer. Cancer 2012, 118, 493-499. [CrossRef] [PubMed]

23. Ponti, G.; Castellsague, E.; Ruini, C.; Percesepe, A.; Tomasi, A. Mismatch repair genes founder mutations and cancer susceptibility in Lynch syndrome. Clin. Genet. 2015, 87, 507-516. [CrossRef] [PubMed]

24. Hamada, T.; Yuan, C.; Yurgelun, M.B.; Perez, K.; Khalaf, N.; Morales-Oyarvide, V.; Babic, A.; Nowak, J.A.; Rubinson, D.A.; Giannakis, M.; et al. Family history of cancer, Ashkenazi Jewish ancestry, and pancreatic cancer risk. Br. J. Cancer 2019, 120, 848-854. [CrossRef] [PubMed]

25. Matsubayashi, H. Familial pancreatic cancer and hereditary syndromes: screening strategy for high-risk individuals. J. Gastroenterol. 2011, 46, 1249-1259. [CrossRef] [PubMed]

26. Kohli, D.R.; Smith, K.R.; Wong, J.; Yu, Z.; Boucher, K.; Faigel, D.O.; Pannala, R.; Burt, R.W.; Curtin, K.; Samadder, N.J. Familial pancreatic cancer risk: a population-based study in Utah. J. Gastroenterol. 2019, 1-7. [CrossRef]

27. Brune, K.A.; Lau, B.; Palmisano, E.; Canto, M.; Goggins, M.G.; Hruban, R.H.; Klein, A.P. Importance of age of onset in pancreatic cancer kindreds. J. Natl. Cancer Inst. 2010, 102, 119-126. [CrossRef]

28. Del Chiaro, M.; Zerbi, A.; Falconi, M.; Bertacca, L.; Polese, M.; Sartori, N.; Boggi, U.; Casari, G.; Longoni, B.M.; Salvia, R.; et al. Cancer Risk among the Relatives of Patients with Pancreatic Ductal Adenocarcinoma. Pancreatol. 2007, 7, 451-458. [CrossRef]

29. Howes, N.; Lerch, M.M.; Greenhalf, W.; Stocken, D.D.; Ellis, I.; Simon, P.; Truninger, K.; Ammann, R.; Cavallini, G.; Charnley, R.M.; et al. Clinical and genetic characteristics of hereditary pancreatitis in Europe. Clin. Gastroenterol. Hepatol. 2004, 2, 252-261. [CrossRef]

30. Schneider, R.; Slater, E.P.; Sina, M.; Habbe, N.; Fendrich, V.; Matthäi, E.; Langer, P.; Bartsch, D.K. German national case collection for familial pancreatic cancer (FaPaCa): ten years experience. Fam. Cancer 2011, 10, 323-330. [CrossRef] 
31. Langer, P.; Kann, P.H.; Fendrich, V.; Habbe, N.; Schneider, M.; Sina, M.; Slater, E.P.; Heverhagen, J.T.; Gress, T.M.; Rothmund, M.; et al. Five years of prospective screening of high-risk individuals from families with familial pancreatic cancer. Gut 2009, 58, 1410-1418. [CrossRef] [PubMed]

32. Mcfaul, C.D.; Greenhalf, W.; Earl, J.; Howes, N.; Neoptolemos, J.P.; Kress, R.; Sina-Frey, M.; Rieder, H.; Hahn, S.; Bartsch, D.K. Anticipation in familial pancreatic cancer. Gut 2006, 55, 252-258. [CrossRef] [PubMed]

33. Humphris, J.L.; Johns, A.L.; Simpson, S.H.; Cowley, M.J.; Pajic, M.; Chang, D.K.; Nagrial, A.M.; Chin, V.T.; Chantrill, L.A.; Pinese, M.; et al. Clinical and pathologic features of familial pancreatic cancer. Cancer 2014, 120, 3669-3675. [CrossRef] [PubMed]

34. Takaori, K.; Hruban, R.H.; Maitra, A.; Tanigawa, N. Pancreatic intraepithelial neoplasia. Pancreas 2004, 28 , 257-262. [CrossRef] [PubMed]

35. Brune, K.; Abe, T.; Canto, M.; O’Malley, L.; Klein, A.P.; Maitra, A.; Adsay, N.V.; Fishman, E.K.; Cameron, J.L.; Yeo, C.J.; et al. Multifocal neoplastic precursor lesions associated with lobular atrophy of the pancreas in patients having a strong family history of pancreatic cancer. Am. J. Surg. Pathol. 2006, 30, 1067-1076. [PubMed]

36. Shi, C.; Klein, A.P.; Goggins, M.; Maitra, A.; Canto, M.; Ali, S.; Schulick, R.; Palmisano, E.; Hruban, R.H. Increased Prevalence of Precursor Lesions in Familial Pancreatic Cancer Patients. Clin. Cancer Res. 2009, 15, 7737-7743. [CrossRef] [PubMed]

37. Singhi, A.D.; Ishida, H.; Ali, S.Z.; Goggins, M.; Canto, M.; Wolfgang, C.L.; Meriden, Z.; Roberts, N.; Klein, A.P.; Hruban, R.H. A histomorphologic comparison of familial and sporadic pancreatic cancers. Pancreatol. 2015, 15, 387-391. [CrossRef]

38. Abe, T.; Fukushima, N.; Brune, K.; Boehm, C.; Sato, N.; Matsubayashi, H.; Canto, M.; Petersen, G.M.; Hruban, R.H.; Goggins, M. Genome-Wide Allelotypes of Familial Pancreatic Adenocarcinomas and Familial and Sporadic Intraductal Papillary Mucinous Neoplasms. Clin. Cancer Res. 2007, 13, 6019-6025. [CrossRef]

39. Norris, A.L.; Roberts, N.J.; Jones, S.; Wheelan, S.J.; Papadopoulos, N.; Vogelstein, B.; Kinzler, K.W.; Hruban, R.H.; Klein, A.P.; Eshleman, J.R. Familial and sporadic pancreatic cancer share the same molecular pathogenesis. Fam. Cancer 2015, 14, 95-103. [CrossRef]

40. Brune, K.; Hong, S.-M.; Li, A.; Yachida, S.; Abe, T.; Griffith, M.; Yang, D.; Omura, N.; Eshleman, J.; Canto, M.; et al. Genetic and epigenetic alterations of familial pancreatic cancers. Cancer Epidemiol. Biomarkers Prev. 2008, 17, 3536-3542. [CrossRef]

41. Golan, T.; Hammel, P.; Reni, M.; Van Cutsem, E.; Macarulla, T.; Hall, M.J.; Park, J.-O.; Hochhauser, D.; Arnold, D.; Oh, D.-Y.; et al. Maintenance Olaparib for Germline BRCA-Mutated Metastatic Pancreatic Cancer. New Engl. J. Med. 2019, 381, 317-327. [CrossRef] [PubMed]

42. Roberts, N.J.; Jiao, Y.; Yu, J.; Kopelovich, L.; Petersen, G.M.; Bondy, M.L.; Gallinger, S.; Schwartz, A.G.; Syngal, S.; Cote, M.L.; et al. ATM mutations in patients with hereditary pancreatic cancer. Cancer Discov. 2012, 2, 41-46. [CrossRef] [PubMed]

43. Takai, E.; Yachida, S.; Shimizu, K.; Furuse, J.; Kubo, E.; Ohmoto, A.; Suzuki, M.; Hruban, R.H.; Okusaka, T.; Morizane, C.; et al. Germline mutations in Japanese familial pancreatic cancer patients. Oncotarget 2016, 7, 74227-74235. [CrossRef] [PubMed]

44. Axilbund, J.E.; Argani, P.; Kamiyama, M.; Palmisano, E.; Raben, M.; Borges, M.; Brune, K.A.; Goggins, M.; Hruban, R.H.; Klein, A.P. Absence of germline BRCA1 mutations in familial pancreatic cancer patients. Cancer Boil. Ther. 2009, 8, 131-135. [CrossRef]

45. Lynch, H.T.; Deters, C.A.; Snyder, C.L.; Lynch, J.F.; Villeneuve, P.; Silberstein, J.; Martin, H.; Narod, S.A.; Brand, R.E. BRCA1 and pancreatic cancer: pedigree findings and their causal relationships. Cancer Genet. Cytogenet. 2005, 158, 119-125. [CrossRef]

46. Goggins, M.; Schutte, M.; Lu, J.; Moskaluk, C.A.; Weinstein, C.L.; Petersen, G.M.; Yeo, C.J.; Jackson, C.E.; Lynch, H.T.; Hruban, R.H.; et al. Germline BRCA2 gene mutations in patients with apparently sporadic pancreatic carcinomas. Cancer Res. 1996, 56, 5360-5364.

47. Bartsch, D.K.; Krysewski, K.; Sina-Frey, M.; Fendrich, V.; Rieder, H.; Langer, P.; Kress, R.; Schneider, M.; Hahn, S.A.; Slater, E.P. Low Frequency of CHEK2 Mutations in Familial Pancreatic Cancer. Fam. Cancer 2006, 5, 305-308. [CrossRef]

48. Jones, S.; Hruban, R.H.; Kamiyama, M.; Borges, M.; Zhang, X.; Parsons, D.W.; Lin, J.C.-H.; Palmisano, E.; Brune, K.; Jaffee, E.M.; et al. Exomic sequencing identifies PALB2 as a pancreatic cancer susceptibility gene. Sci. 2009, 324, 217. [CrossRef] 
49. Slater, E.; Langer, P.; Niemczyk, E.; Strauch, K.; Butler, J.; Habbe, N.; Neoptolemos, J.; Greenhalf, W.; Bartsch, D. PALB2 mutations in European familial pancreatic cancer families. Clin. Genet. 2010, 78, 490-494. [CrossRef]

50. Figer, A.; Irmin, L.; Geva, R.; Flex, D.; Sulkes, J.; Sulkes, A.; Friedman, E. The rate of the 6174delT founder Jewish mutation in BRCA2 in patients with non-colonic gastrointestinal tract tumours in Israel. Br. J. Cancer 2001, 84, 478-481. [CrossRef]

51. Martin, S.T.; Matsubayashi, H.; Rogers, C.D.; Philips, J.; Couch, F.J.; Brune, K.; Yeo, C.J.; Kern, S.E.; Hruban, R.H.; Goggins, M. Increased prevalence of the BRCA2 polymorphic stop codon K3326X among individuals with familial pancreatic cancer. Oncogene 2005, 24, 3652-3656. [CrossRef] [PubMed]

52. Skoulidis, F.; Cassidy, L.D.; Pisupati, V.; Jonasson, J.G.; Bjarnason, H.; Eyfjörd, J.E.; Karreth, F.A.; Lim, M.; Barber, L.M.; Clatworthy, S.A.; et al. Germline Brca2 Heterozygosity Promotes KrasG12D -Driven Carcinogenesis in a Murine Model of Familial Pancreatic Cancer. Cancer Cell 2010, 18, 499-509. [CrossRef] [PubMed]

53. Matsubayashi, H.; Watanabe, H.; Nishikura, K.; Ajioka, Y.; Kijima, H.; Saito, T. Determination of pancreatic ductal carcinoma histogenesis by analysis of mucous quality and K-ras mutation. Cancer 1998, 82, 651-660. [CrossRef]

54. Schrader, K.A.; Cheng, D.T.; Joseph, V.; Prasad, M.; Walsh, M.; Zehir, A.; Ni, A.; Thomas, T.; Benayed, R.; Ashraf, A.; et al. Germline Variants in Targeted Tumor Sequencing Using Matched Normal DNA. JAMA Oncol. 2016, 2, 104-111. [CrossRef]

55. Turner, N.; Tutt, A.; Ashworth, A. Hallmarks of 'BRCAness' in sporadic cancers. Nat. Rev. Cancer 2004, 4, 814-819. [CrossRef]

56. Kiyozumi, Y.; Matsubayashi, H.; Horiuchi, Y.; Higashigawa, S.; Oishi, T.; Abe, M.; Ohnami, S.; Urakami, K.; Nagashima, T.; Kusuhara, M.; et al. Germline mismatch repair gene variants analyzed by universal sequencing in Japanese cancer patients. Cancer Med. 2019. [CrossRef]

57. Henriksen, A.; Dyhl-Polk, A.; Chen, I.; Nielsen, D. Checkpoint inhibitors in pancreatic cancer. Cancer Treat. Rev. 2019, 78, 17-30. [CrossRef]

58. Petersen, G.M.; De Andrade, M.; Goggins, M.; Hruban, R.H.; Bondy, M.; Korczak, J.F.; Gallinger, S.; Lynch, H.T.; Syngal, S.; Rabe, K.G.; et al. Pancreatic Cancer Genetic Epidemiology Consortium. Cancer Epidemiol. Biomarkers Prev. 2006, 15, 704-710. [CrossRef]

59. Del Chiaro, M.; Zerbi, A.; Capurso, G.; Zamboni, G.; Maisonneuve, P.; Presciuttini, S.; Arcidiacono, P.G.; Calculli, L.; Falconi, M. Familial pancreatic cancer in Italy. Risk assessment, screening programs and clinical approach: A position paper from the Italian Registry. Dig. Liver Dis. 2010, 42, 597-605. [CrossRef]

60. Mocci, E.; Ponce, C.G.; Earl, J.; Márquez, M.; Solera, J.; Salazar-López, M.-T.; Calcedo-Arnáiz, C.; Vazquez-Sequeiros, E.; Montáns, J.; Muñoz-Beltrán, M.; et al. PanGen-Fam: Spanish registry of hereditary pancreatic cancer. Eur. J. Cancer 2015, 51, 1911-1917. [CrossRef]

61. Wada, K.; Takaori, K.; Traverso, L.W.; Hruban, R.H.; Furukawa, T.; Brentnall, T.A.; Hatori, T.; Sano, K.; Takada, T.; Majima, Y.; et al. Clinical importance of Familial Pancreatic Cancer Registry in Japan: a report from kick-off meeting at International Symposium on Pancreas Cancer. J. Hepatobiliary Pancreat. Sci. 2013, 20, 557-566. [CrossRef] [PubMed]

62. Brand, R.E.; Lerch, M.M.; Rubinstein, W.S.; Neoptolemos, J.P.; Whitcomb, D.C.; Hruban, R.H.; Brentnall, T.A.; Lynch, H.T.; Canto, M.I. Advances in counselling and surveillance of patients at risk for pancreatic cancer. Gut 2007, 56, 1460-1469. [CrossRef] [PubMed]

63. Canto, M.I.; Harinck, F.; Hruban, R.H.; Offerhaus, G.J.; Poley, J.W.; Kamel, I.; Nio, Y.; Schulick, R.S.; Bassi, C.; Kluijt, I.; et al. International Cancer of the Pancreas Screening (CAPS) Consortium summit on the management of patients with increased risk for familial pancreatic cancer. Gut 2013, 62, 339-347. [CrossRef] [PubMed]

64. Tanaka, M.; Castillo, C.F.-D.; Adsay, V.; Chari, S.; Falconi, M.; Jang, J.-Y.; Kimura, W.; Levy, P.; Pitman, M.B.; Schmidt, C.M.; et al. International consensus guidelines 2012 for the management of IPMN and MCN of the pancreas. Pancreatol. 2012, 12, 183-197. [CrossRef] [PubMed]

65. Sud, A.; Wham, D.; Catalano, M.; Guda, N.M. Promising outcomes of screening for pancreatic cancer by genetic testing and endoscopic ultrasound. Pancreas 2014, 43, 458-461. [CrossRef]

66. Lynch, S.M.; Vrieling, A.; Lubin, J.H.; Kraft, P.; Mendelsohn, J.B.; Hartge, P.; Canzian, F.; Steplowski, E.; Arslan, A.A.; Gross, M.; et al. Cigarette Smoking and Pancreatic Cancer: A Pooled Analysis From the Pancreatic Cancer Cohort Consortium. Am. J. Epidemiol. 2009, 170, 403-413. [CrossRef] 
67. Larsson, S.C.; Orsini, N.; Wolk, A. Body mass index and pancreatic cancer risk: A meta-analysis of prospective studies. Int. J. Cancer 2007, 120, 1993-1998. [CrossRef]

68. Stolzenberg-Solomon, R.Z.; Adams, K.; Leitzmann, M.; Schairer, C.; Michaud, D.S.; Hollenbeck, A.; Schatzkin, A.; Silverman, D.T. Adiposity, physical activity, and pancreatic cancer in the National Institutes of Health-AARP Diet and Health Cohort. Am. J. Epidemiol. 2008, 167, 586-597. [CrossRef]

69. Huxley, R.; Ansary-Moghaddam, A.; De González, A.B.; Barzi, F.; Woodward, M. Type-II diabetes and pancreatic cancer: a meta-analysis of 36 studies. Br. J. Cancer 2005, 92, 2076-2083. [CrossRef]

70. Lowenfels, A.B.; Maisonneuve, P.; Cavallini, G.; Ammann, R.W.; Lankisch, P.G.; Andersen, J.R.; Dimagno, E.P.; Andren-Sandberg, A.; Domellof, L. Pancreatitis and the risk of pancreatic cancer. International Pancreatitis Study Group. N. Engl. J. Med. 1993, 328, 1433-1437. [CrossRef]

71. Talamini, G.; Falconi, M.; Bassi, C.; Sartori, N.; Salvia, R.; Caldiron, E.; Frulloni, L.; Di Francesco, V.; Vaona, B.; Bovo, P.; et al. Incidence of cancer in the course of chronic pancreatitis. Am. J. Gastroenterol. 1999, 94, 1253-1260. [CrossRef] [PubMed]

72. Tanaka, S.; Nakao, M.; Ioka, T.; Takakura, R.; Takano, Y.; Tsukuma, H.; Uehara, H.; Suzuki, R.; Fukuda, J. Slight Dilatation of the Main Pancreatic Duct and Presence of Pancreatic Cysts as Predictive Signs of Pancreatic Cancer: A Prospective Study. Radiology 2010, 254, 965-972. [CrossRef] [PubMed]

73. Canto, M.I.; Goggins, M.; Hruban, R.H.; Petersen, G.M.; Giardiello, F.M.; Yeo, C.; Fishman, E.K.; Brune, K.; Axilbund, J.; Griffin, C.; et al. Screening for Early Pancreatic Neoplasia in High-Risk Individuals: A Prospective Controlled Study. Clin. Gastroenterol. Hepatol. 2006, 4, 766-781. [CrossRef] [PubMed]

74. Mucci, L.A.; Hjelmborg, J.B.; Harris, J.R.; Czene, K.; Havelick, D.J.; Scheike, T.; Graff, R.E.; Holst, K.; Möller, S.; Unger, R.H.; et al. Familial Risk and Heritability of Cancer Among Twins in Nordic Countries. JAMA 2016, 315, 68-76. [CrossRef] [PubMed]

75. Brentnall, T.A.; Bronner, M.P.; Byrd, D.R.; Haggitt, R.C.; Kimmey, M.B. Early diagnosis and treatment of pancreatic dysplasia in patients with a family history of pancreatic cancer. Ann. Intern. Med. 1999, 131, 247-255. [CrossRef] [PubMed]

76. Canto, M.I.; Hruban, R.H.; Fishman, E.K.; Kamel, I.R.; Schulick, R.; Zhang, Z.; Topazian, M.; Takahashi, N.; Fletcher, J.; Petersen, G.; et al. Frequent detection of pancreatic lesions in asymptomatic high-risk individuals. Gastroenterol. 2012, 142, 796-804. [CrossRef]

77. Canto, M.I.; Almario, J.A.; Schulick, R.D.; Yeo, C.J.; Klein, A.; Blackford, A.; Shin, E.J.; Sanyal, A.; Yenokyan, G.; Lennon, A.M.; et al. Risk of Neoplastic Progression in Individuals at High Risk for Pancreatic Cancer Undergoing Long-term Surveillance. Gastroenterol. 2018, 155, 740-751.e2. [CrossRef]

78. Yasuda, I.; Iwashita, T.; Doi, S.; Nakashima, M.; Moriwaki, H. ROLE OF EUS IN THE EARLY DETECTION OF SMALL PANCREATIC CANCER. Dig. Endosc. 2011, 23, 22-25. [CrossRef]

79. Eisen, G.M.; Dominitz, J.A.; Faigel, D.O.; Goldstein, J.A.; Petersen, B.T.; Raddawi, H.M.; Ryan, M.E.; Vargo, J.J., 2nd; Young, H.S.; Wheeler-Harbaugh, J.; et al. Guidelines for credentialing and granting privileges for endoscopic ultrasound. Gastrointest Endosc. 2001, 54, 811-814. [CrossRef]

80. Canto, M.I.; Goggins, M.; Yeo, C.J.; Griffin, C.; Axilbund, J.E.; Brune, K.; Ali, S.Z.; Jagannath, S.; Petersen, G.M.; Fishman, E.K.; et al. Screening for pancreatic neoplasia in high-risk individuals: an EUS-based approach. Clin. Gastroenterol. Hepatol. 2004, 2, 606-621. [CrossRef]

81. Topazian, M.; Enders, F.; Kimmey, M.; Brand, R.; Chak, A.; Clain, J.; Cunningham, J.; Eloubeidi, M.; Gerdes, H.; Gress, F.; et al. Interobserver agreement for EUS findings in familial pancreatic-cancer kindreds. Gastrointest. Endosc. 2007, 66, 62-67. [CrossRef] [PubMed]

82. Sheel, A.R.G.; Harrison, S.; Sarantitis, I.; Nicholson, J.A.; Hanna, T.; Grocock, C.; Raraty, M.; Ramesh, J.; Farooq, A.; Costello, E.; et al. Identification of Cystic Lesions by Secondary Screening of Familial Pancreatic Cancer (FPC) Kindreds Is Not Associated with the Stratified Risk of Cancer. Am. J. Gastroenterol. 2019, 114, 155-164. [CrossRef] [PubMed]

83. Potjer, T.P.; Schot, I.; Langer, P.; Heverhagen, J.T.; Wasser, M.N.; Slater, E.P.; Kloppel, G.; Morreau, H.M.; Bonsing, B.A.; de Vos Tot Nederveen Cappel, W.H.; et al. Variation in precursor lesions of pancreatic cancer among high-risk groups. Clin. Cancer Res. 2013, 19, 442-449. [CrossRef]

84. Konings, I.C.A.W.; Harinck, F.; Poley, J.-W.; Aalfs, C.M.; Van Rens, A.; Krak, N.C.; Wagner, A.; Nio, C.Y.; Sijmons, R.H.; Van Dullemen, H.M.; et al. Prevalence and Progression of Pancreatic Cystic Precursor Lesions Differ Between Groups at High Risk of Developing Pancreatic Cancer. Pancreas 2017, 46, 28-34. [CrossRef] [PubMed] 
85. Sato, N.; Rosty, C.; Jansen, M.; Fukushima, N.; Ueki, T.; Yeo, C.J.; Cameron, J.L.; Iacobuzio-Donahue, C.A.; Hruban, R.H.; Goggins, M. STK11/LKB1 Peutz-Jeghers Gene Inactivation in Intraductal Papillary-Mucinous Neoplasms of the Pancreas. Am. J. Pathol. 2001, 159, 2017-2022. [CrossRef]

86. Sudo, T.; Murakami, Y.; Uemura, K.; Hayashidani, Y.; Takesue, Y.; Sueda, T. Development of an intraductal papillary-mucinous neoplasm of the pancreas in a patient with familial adenomatous polyposis. Pancreas 2005, 31, 428-429. [CrossRef]

87. McWilliams, R.R.; Petersen, G.M.; Rabe, K.G.; Holtegaard, L.M.; Lynch, P.J.; Bishop, M.D.; Highsmith, W.E., Jr. Cystic fibrosis transmembrane conductance regulator (CFTR) gene mutations and risk for pancreatic adenocarcinoma. Cancer 2009, 116, 203-209. [CrossRef]

88. Masamune, A.; Kikuta, K.; Hamada, S.; Nakano, E.; Kume, K.; Inui, A.; Shimizu, T.; Takeyama, Y.; Nio, M.; Shimosegawa, T. Nationwide survey of hereditary pancreatitis in Japan. J. Gastroenterol. 2018, 53, 152-160. [CrossRef]

89. Goggins, M.; Offerhaus, G.J.; Hilgers, W.; Griffin, C.A.; Shekher, M.; Tang, D.; Sohn, T.A.; Yeo, C.J.; Kern, S.E.; Hruban, R.H. Pancreatic adenocarcinomas with DNA replication errors (RER+) are associated with wild-type K-ras and characteristic histopathology. Poor differentiation, a syncytial growth pattern, and pushing borders suggest RER+. Am. J. Pathol. 1998, 152, 1501-1507.

90. Uemura, S.; Matsubayashi, H.; Kiyozumi, Y.; Uesaka, K.; Yamamoto, Y.; Sasaki, K.; Abe, M.; Urakami, K.; Kusuhara, M.; Yamaguchi, K. Pancreatic adenocarcinoma with a germline PTEN p.Arg234Gln mutation. Fam Cancer 2018, 17, 255-259. [CrossRef]

91. Yamao, K.; Sawaki, A.; Mizuno, N.; Shimizu, Y.; Yatabe, Y.; Koshikawa, T. Endoscopic ultrasound-guided fine-needle aspiration biopsy (EUS-FNAB): past, present, and future. J. Gastroenterol. 2005, 40, 1013-1023. [CrossRef] [PubMed]

92. Matsubayashi, H.; Sasaki, K.; Ono, S.; Abe, M.; Ishiwatari, H.; Fukutomi, A.; Uesaka, K.; Ono, H. Pathological and Molecular Aspects to Improve Endoscopic Ultrasonography-Guided Fine-Needle Aspiration From Solid Pancreatic Lesions. Pancreas 2018, 47, 163-172. [CrossRef] [PubMed]

93. Uehara, H.; Ikezawa, K.; Kawada, N.; Fukutake, N.; Katayama, K.; Takakura, R.; Takano, Y.; Ishikawa, O.; Takenaka, A. Diagnostic accuracy of endoscopic ultrasound-guided fine needle aspiration for suspected pancreatic malignancy in relation to the size of lesions. J. Gastroenterol. Hepatol. 2011, 26, 1256-1261. [CrossRef]

94. Matsubayashi, H.; Sasaki, K.; Nagata, K.; Kanemoto, H.; Kiuchi, R.; Ono, H. Pancreatic carcinoma mimicking diffuse-type autoimmune pancreatitis: Important diagnostic role of pancreatic juice cytology using endoscopic naso-pancreatic drainage. J. Dig. Dis. 2012, 13, 287-290. [CrossRef] [PubMed]

95. Hanada, K.; Okazaki, A.; Hirano, N.; Izumi, Y.; Minami, T.; Ikemoto, J.; Kanemitsu, K.; Hino, F. Effective screening for early diagnosis of pancreatic cancer. Best Pr. Res. Clin. Gastroenterol. 2015, 29, 929-939. [CrossRef] [PubMed]

96. Matsubayashi, H.; Kasuya, K.; Ajioka, Y.; Itoi, T.; Yasuda, A.; Watanabe, H. Pathology of early pancreatic cancer. Rinsho Kagaku 1995, 31, 318-326.

97. Minaga, K.; Takenaka, M.; Katanuma, A.; Kitano, M.; Yamashita, Y.; Kamata, K.; Yamao, K.; Watanabe, T.; Maguchi, H.; Kudo, M. Needle Tract Seeding: An Overlooked Rare Complication of Endoscopic Ultrasound-Guided Fine-Needle Aspiration. Oncol. 2017, 93, 107-112. [CrossRef]

98. Kauff, N.D.; Barakat, R.R. Risk-Reducing Salpingo-Oophorectomy in Patients With Germline Mutations inBRCA1orBRCA. J. Clin. Oncol. 2007, 25, 2921-2927. [CrossRef]

99. Nimptsch, U.; Krautz, C.; Weber, G.F.; Mansky, T.; Grützmann, R. Nationwide In-hospital Mortality Following Pancreatic Surgery in Germany is Higher than Anticipated. Ann. Surg. 2016, 264, 1-1090. [CrossRef]

100. Müller, M.W.; Friess, H.; Kleeff, J.; Dahmen, R.; Wagner, M.; Hinz, U.; Breisch-Girbig, D.; Ceyhan, G.O.; Büchler, M.W. Is There Still a Role for Total Pancreatectomy? Ann. Surg. 2007, 246, 966-975. [CrossRef]

101. Mehrabi, A.; Golriz, M.; Adili-Aghdam, F.; Hafezi, M.; Ashrafi, M.; Morath, C.; Zeier, M.; Hackert, T.; Schemmer, P. Expanding the Indications of Pancreas Transplantation Alone. Pancreas 2014, 43, 1190-1193. [CrossRef] [PubMed]

102. Miyazaki, M.; Yoshitomi, H.; Shimizu, H.; Ohtsuka, M.; Yoshidome, H.; Furukawa, K.; Takayasiki, T.; Kuboki, S.; Okamura, D.; Suzuki, D.; et al. Repeat pancreatectomy for pancreatic ductal cancer recurrence in the remnant pancreas after initial pancreatectomy: Is it worthwhile? Surgery 2014, 155, 58-66. [CrossRef] [PubMed] 
103. Heidt, D.G.; Burant, C.; Simeone, D.M. Total Pancreatectomy: Indications, Operative Technique, and Postoperative Sequelae. J. Gastrointest. Surg. 2007, 11, 209-216. [CrossRef] [PubMed]

104. Poley, J.W.; Kluijt, I.; Gouma, D.J.; Harinck, F.; Wagner, A.; Aalfs, C.; Van Eijck, C.H.J.; Cats, A.; Kuipers, E.J.; Nio, Y.; et al. The Yield of First-Time Endoscopic Ultrasonography in Screening Individuals at a High Risk of Developing Pancreatic Cancer. Am. J. Gastroenterol. 2009, 104, 2175-2181. [CrossRef] [PubMed]

105. Verna, E.C.; Hwang, C.; Stevens, P.D.; Rotterdam, H.; Stavropoulos, S.N.; Sy, C.D.; Prince, M.A.; Chung, W.K.; Fine, R.L.; Chabot, J.A.; et al. Pancreatic Cancer Screening in a Prospective Cohort of High-Risk Patients: A Comprehensive Strategy of Imaging and Genetics. Clin. Cancer Res. 2010, 16, 5028-5037. [CrossRef]

106. Ludwig, E.; Olson, S.H.; Bayuga, S.; Simon, J.; A Schattner, M.; Gerdes, H.; Allen, P.J.; Jarnagin, W.R.; Kurtz, R.C. Feasibility and yield of screening in relatives from familial pancreatic cancer families. Am. J. Gastroenterol. 2011, 106, 946-954. [CrossRef]

107. Vasen, H.F.; Wasser, M.; Van Mil, A.; Tollenaar, R.A.; Konstantinovski, M.; Gruis, N.A.; Bergman, W.; Hes, F.J.; Hommes, D.W.; Offerhaus, G.J.A.; et al. Magnetic Resonance Imaging Surveillance Detects Early-Stage Pancreatic Cancer in Carriers of a p16-Leiden Mutation. Gastroenterology 2011, 140, 850-856. [CrossRef]

108. Al-Sukhni, W.; Borgida, A.; Rothenmund, H.; Holter, S.; Semotiuk, K.; Grant, R.; Wilson, S.; Moore, M.; Narod, S.; Jhaveri, K.; et al. Screening for pancreatic cancer in a high-risk cohort: an eight-year experience. J Gastrointest Surg 2012, 16, 771-783. [CrossRef]

109. Del Chiaro, M.; Verbeke, C.S.; Kartalis, N.; Mucelli, R.P.; Gustafsson, P.; Hansson, J.; Haas, S.L.; Segersvärd, R.; Andrén-Sandbergke, Å.; Löhr, J.-M. Short-term Results of a Magnetic Resonance Imaging-Based Swedish Screening Program for Individuals at Risk for Pancreatic Cancer. JAMA Surg. 2015, 150, 512-518. [CrossRef]

110. Vasen, H.; Ibrahim, I.; Ponce, C.G.; Slater, E.P.; Matthäi, E.; Carrato, A.; Earl, J.; Robbers, K.; Van Mil, A.M.; Potjer, T.; et al. Benefit of Surveillance for Pancreatic Cancer in High-Risk Individuals: Outcome of Long-Term Prospective Follow-Up Studies From Three European Expert Centers. J. Clin. Oncol. 2016, 34, 2010-2019. [CrossRef]

111. Tuaeva, N.O.; Falzone, L.; Porozov, Y.B.; Nosyrev, A.E.; Trukhan, V.M.; Kovatsi, L.; Spandidos, D.A.; Drakoulis, N.; Kalogeraki, A.; Mamoulakis, C.; et al. Translational Application of Circulating DNA in Oncology: Review of the Last Decades Achievements. Cells 2019, 8, 1251. [CrossRef] [PubMed]

112. Liu, X.; Liu, L.; Ji, Y.; Li, C.; Wei, T.; Yang, X.; Zhang, Y.; Cai, X.; Gao, Y.; Xu, W.; et al. Enrichment of short mutant cell-free DNA fragments enhanced detection of pancreatic cancer. EBioMedicine 2019, 41, 345-356. [CrossRef] [PubMed]

113. Allenson, K.; Castillo, J.; Lucas, F.A.S.; Scelo, G.; Kim, D.U.; Bernard, V.; Davis, G.; Kumar, T.; Katz, M.; Overman, M.J.; et al. High prevalence of mutant KRAS in circulating exosome-derived DNA from early-stage pancreatic cancer patients. Ann. Oncol. 2017, 28, 741-747. [CrossRef] [PubMed]

114. Vila-Navarro, E.; Vila-Casadesus, M.; Moreira, L.; Duran-Sanchon, S.; Sinha, R.; Gines, A.; Fernandez-Esparrach, G.; Miquel, R.; Cuatrecasas, M.; Castells, A.; et al. MicroRNAs for Detection of Pancreatic Neoplasia. Biomarker Discovery by Next-generation Sequencing and Validation in 2 Independent Cohorts. Ann. Surg. 2017, 265, 1226-1234. [CrossRef]

115. Vandenbrouck, Y.; Christiany, D.; Combes, F.; Loux, V.; Brun, V. Bioinformatics Tools and Workflow to Select Blood Biomarkers for Early Cancer Diagnosis: An Application to Pancreatic Cancer. Proteomics 2019, e1800489. [CrossRef]

116. Lambert, A.; Schwarz, L.; Borbath, I.; Henry, A.; Van Laethem, J.L.; Malka, D.; Ducreux, M.; Conroy, T. An update on treatment options for pancreatic adenocarcinoma. Ther. Adv. Med. Oncol. 2019, 11, 1-43. [CrossRef]

117. Golan, T.; Kanji, Z.S.; Epelbaum, R.; Devaud, N.; Dagan, E.; Holter, S.; Aderka, D.; Paluch-Shimon, S.; Kaufman, B.; Gershoni-Baruch, R.; et al. Overall survival and clinical characteristics of pancreatic cancer in BRCA mutation carriers. Br. J. Cancer 2014, 111, 1132-1138. [CrossRef]

118. Kondo, T.; Kanai, M.; Kou, T.; Sakuma, T.; Mochizuki, H.; Kamada, M.; Nakatsui, M.; Uza, N.; Kodama, Y.; Masui, T.; et al. Association between homologous recombination repair gene mutations and response to oxaliplatin in pancreatic cancer. Oncotarget 2018, 9, 19817-19825. [CrossRef]

(C) 2019 by the authors. Licensee MDPI, Basel, Switzerland. This article is an open access article distributed under the terms and conditions of the Creative Commons Attribution (CC BY) license (http://creativecommons.org/licenses/by/4.0/). 